\title{
Crucial role of OX40/OX40L signaling in a murine model of asthma
}

\author{
WEI LEI $^{1 *}$, DAXIONG ZENG ${ }^{1 *}$, GAOQIN LIU $^{2 *}$, YEHAN ZHU $^{1}$, JIAJIA WANG ${ }^{1}$, \\ HONGYA WU ${ }^{3}$, JUNHONG JIANG ${ }^{1}$ and JIANAN HUANG ${ }^{1}$ \\ Departments of ${ }^{1}$ Respiratory Medicine and ${ }^{2}$ Ophthalmology; ${ }^{3}$ Jiangsu Key Laboratory of Gastrointestinal Tumor \\ Immunology, The First Affiliated Hospital of Soochow University, Suzhou, Jiangsu 215006, P.R. China
}

Received January 9, 2017; Accepted August 31, 2017

DOI: $10.3892 / \mathrm{mmr} .2018 .8453$

\begin{abstract}
The aim of the present study was to explore the roles of OX40/OX40 ligand (OX40L) signaling and $\mathrm{OX} 40^{+} \mathrm{T}$ cells in ovalbumin (OVA)-induced mouse asthma model. Asthma was induced by OVA exposure and subsequent co-treatment with OX40L protein, neutralizing anti-OX40L blocking antibody, $\mathrm{OX} 40^{+} \mathrm{T}$ cells or PBS. The protein expression levels of interleukin (IL)-4, IL-6, IL-13, IL-17, tumor necrosis factor (TNF)- $\alpha$ and interferon (IFN)- $\gamma$ in bronchoalveolar lavage fluid (BALF) were examined using murine cytokine-specific ELISA. Eosinophil accumulation as well as proliferation and apoptosis of $\mathrm{T}$ cells in BALF were detected by Cell Counting kit- 8 and flow cytometric assays. Expression of the apoptosis-related protein cleaved caspase- 3 was examined in $\mathrm{OX} 40^{+} \mathrm{T}$ cells using western blot assay. Flow cytometric analysis revealed that OVA-treated mice that were co-treated with OX40L or $\mathrm{OX} 40^{+} \mathrm{T}$ cells exhibited higher eosinophil infiltration compared with control mice treated only with OVA, whereas neutralizing anti-OX40L blocking antibody inhibited eosinophil infiltration. ELISA assays demonstrated that the expression of IL-4, IL-6, IL-13, IL-17, TNF- $\alpha$ and IFN- $\gamma$ in BALF in OX40L-treated and OX40 ${ }^{+} \mathrm{T}$ cell-treated mice was increased compared with expression levels in control mice. Treatment with OX40L protein effectively reduced apoptosis of $\mathrm{T}$ cells and the expression of cleaved caspase- 3 in $\mathrm{T}$ cells. OX40L-treated and $\mathrm{OX} 40^{+} \mathrm{T}$ cell-treated mice exhibited increased asthma through OX40/OX40L signaling, which probably promoted inflammatory factor expression, eosinophil infiltration and $\mathrm{T}$ cell proliferation.
\end{abstract}

Correspondence to: Dr Junhong Jiang or Dr Jianan Huang, Department of Respiratory Medicine, The First Affiliated Hospital of Soochow University, 899 Pinghai Road, Suzhou, Jiangsu 215006, P.R. China

E-mail: jiang20001969@163.com

E-mail: huang_jian_an@163.com

*Contributed equally

Key words: OX40, OX40 ligand, T cell, cytokine, asthma

\section{Introduction}

Asthma is a complex disease that involves a number of genetic and environmental influences (1). The chronic inflammation in asthma is characterized by eosinophilic recruitment, airway hyperresponsiveness(AHR),gobletcell hyperplasia/metaplasia, epithelial hypertrophy/hyperplasia, mucus hypersecretion, collagen deposition, smooth muscle cell hypertrophy/hyperplasia and subepithelial fibrosis $(2,3)$. Worldwide $~ 300$ million people suffer from asthma, and this number is predicted to rise over the next 10-15 years to $>400$ million (4). It has been reported that chronic airway inflammatory processes lead to the recruitment of activated eosinophils and T helper 2 (Th2) lymphocytes to the site of injury and an improper immune response to common allergens (5). Recurrent inflammation and subsequent abnormalities in the tissue repair mechanisms may lead to structural alterations in the airway wall that may develop the clinically detectable features of epithelial injury, goblet cell hyperplasia, subepithelial thickening, airway hyperplasia and angiogenesis (6). Inflammatory infiltrates in the airways that are characteristic of asthma may affect the structural cells and lead to AHR (7). There are a number of different immune cells in the infiltrates, including T lymphocytes that produce cytokines, such as interleukin (IL)-4, IL-5 and IL-13, which serve important roles in the pathogenesis of asthma (8-10). Therefore, targeting these $\mathrm{T}$ lymphocytes may have the potential to effectively treat asthma.

OX40 (also known as CD134) and its binding partner OX40 ligand (OX40L; also known as CD252) are members of the tumor necrosis factor (TNF)/TNF receptor superfamily and are expressed on activated CD4 and CD8 T cells, and on a number of lymphoid and non-lymphoid cells (11). OX40L is mainly expressed by antigen-presenting cells (APCs), such as dendritic cells, but is also expressed by B cells, macrophages and Langerhans cells (12). Dendritic cells in the airway express OX40L in response to epithelial cell-derived thymic stromal lymphopoietin stimulation (TSLP) (13). In vivo studies using murine and nonhuman primate models of asthma have reported that the inhibition of OX40L suppressed TSLP-mediated Th2 inflammation and reduced the number of OX40L $\mathrm{L}^{+}$ dendritic cells in the lungs (14). OX40/OX40L interactions have been demonstrated to serve a central role in numerous inflammatory and autoimmune disease development, which 
suggested that they may be suitable candidates for clinical intervention (15); however, the effects and precise mechanisms of OX40/OX40L signaling in the development of asthma remains unclear. Clarification of the underlying mechanisms of the OX40/OX40L signaling in mediating inflammation, immunoreactions or other cell functions in asthma may lead to improved clinical treatment on asthma.

The present study examined the effects of OX40/OX40L signaling on inflammation and $\mathrm{T}$ cell functions in a mouse asthma model and investigated the possible underlying mechanisms. The aim was to provide a new perspective and deeper understanding of the etiology of asthma and to provide additional evidence for the potential involvement of OX40/OX40L signaling in the development of asthma.

\section{Materials and methods}

Reagents and antibodies. Murine interleukin (IL-) 4 (catalog no. BMS613), IL-6 (catalog no. BMS603-2), IL-13 (catalog no. KMC2221), IL-17 (catalog no. BMS6001), tumor necrosis factor (TNF-) $\alpha$ (catalog no. BMS607-3) and interferon (IFN-) $\gamma$ (catalog no. 88-8314-77) ELISA kits were purchased from Invitrogen (Thermo Fisher Scientific, Inc., Waltham, MA, USA). Ovalbumin (OVA) was purchased from Sigma-Aldrich (Merck KGaA, Darmstadt, Germany). Neutralizing rat anti-OX40L monoclonal antibody was purchased from Bio X Cell (West Lebanon, NH, USA; catalog no. BE0033-1-25MG). Mouse recombinant OX40L protein was purchased from R\&D Systems, Inc. (Minneapolis, MN, USA; catalog no. 1236-OX-025). Rabbit anti-cleaved caspase 3 (Asp175), polyclonal antibody was purchased from Abbexa, Ltd. (Cambridge, UK; catalog no. abx015533). Rabbit anti-NF-кB polyclonal antibody (Aviva Systems Biology, San Diego, CA, USA; catalog no. OAAI00072; phosphorylated (p-)Ser337). Anti-GAPDH antibody was purchased from Beyotime Institute of Biotechnology (Shanghai, China; catalog no. AF0006). Cell Counting Kit-8 (CCK-8) was purchased from Dojindo Molecular Technologies, Inc. (Kumamoto, Japan). Dead Cell Apoptosis kit with Annexin V Alexa Fluor 488 \& propidium iodide (PI) was purchased from Thermo Fisher Scientific, Inc. (catalog no. V13241). Fluorescein isothiocyanate-conjugated rat anti-CD4 monoclonal antibody was purchased from LifeSpan BioSciences, Inc. (Seattle, WA, USA; catalog no. LS-C62734-300). Phycoerythrin (PE-)conjugated goat anti-OX40 polyclonal antibody was purchased from R\&D Systems, Inc. (catalog no. FAB1256P).

Experimental animals. Specific-pathogen-free female BALB/c mice ( $n=156$; age, 6-8 weeks; weight, 20-25 g) were obtained from Shanghai SLAC Laboratory Animal Co. Ltd. (Shanghai, China), and were kept at $19-22^{\circ} \mathrm{C}$ and $40-75 \%$ relative humidity at all times in the animal facility under specific-pathogen-free conditions. A 12-h light/dark cycle was maintained during the course of the present study. Animals were kept in groups of five and fed regular lab chow and water ad libitum. All animal experiments performed in this study conformed to the Guide for the Care and Use of Laboratory Animals (16) and were approved by the Institutional Animal Care and Use Committee of Soochow University (Suzhou, China).
OX40 ${ }^{+}$T cell sorting protocol. Murine $\mathrm{CD}^{+} \mathrm{T}$ cells were obtained from mononuclear cells prepared from the bronchoalveolar lavage fluid (BALF) of 18 OVA-challenged mice or the spleen of $6 \mathrm{BALB} / \mathrm{c}$ mice and T cells were isolated using a Pan T Cell Isolation Kit II (Miltenyi Biotec GmbH, Bergisch Gladbach, Germany; catalog no. 130-095-130) according to the manufacturer's protocol (17) and collected in sterile PBS containing $50 \%$ fetal calf serum (FCS). The purified T cells $\left(10^{6}\right.$ cells $\left./ \mathrm{ml}\right)$ were then cultured in DMEM containing $10 \%$ FCS in a 6-well plate with plate-bound anti-CD3 antibody (3 $\mu \mathrm{g} / \mathrm{ml}$; R\&D Systems, Inc.; catalog no. MAB4841-SP) and soluble anti-CD28 antibody $(10 \mu \mathrm{g} / \mathrm{ml}$; R\&D Systems, Inc.; catalog no. MAB4832-SP), as well as IL-2 $(5 \mathrm{ng} / \mathrm{ml}$; R\&D Systems, Inc.; catalog no. P04351), IL-4 (20 ng/ml; R\&D Systems, Inc.; catalog no. P07750), anti-IFN- $\gamma$ antibody (10 $\mu \mathrm{g} / \mathrm{ml}$; R\&D Systems, Inc.; catalog no. MAB485-SP) and anti-IL-12 antibody (10 $\mu \mathrm{g} / \mathrm{ml}$; R\&D Systems, Inc.; catalog no. AF-419-SP) for 3 days at $37^{\circ} \mathrm{C}$. Cells were subsequently removed, washed and cultured with DMEM containing $10 \%$ FCS for a further 3-6 days at $37^{\circ} \mathrm{C}$ without further stimulation (18). T cells were subsequently processed for the sorting assay with phycoethryin-conjugated OX40 antibodies (10 $\mu 1 / 10^{6}$ cells; R\&D Systems, Inc.; catalog no. FAB1256P) using flow cytometry to isolate $\mathrm{OX} 40^{+} \mathrm{T}$ cells for further in vivo experiments. Cells were analyzed with FlowJo software (version 7.6; FlowJo LLC, Ashland, OR, USA).

Immunization and intervention. Protocols for immunization and intervention were as previously described (19). Briefly, 120 mice were immunized with an intraperitoneal injection of OVA (100 $\mu \mathrm{g}$; Sigma-Aldrich; Merck KGaA) and aluminum hydroxide (2 mg; Pierce; Thermo Fisher Scientific, Inc.) in sterile saline on days 1 and 8. On days 9-14 following the initial sensitization, mice were challenged intranasally with $20 \mu \mathrm{g}$ of $2 \%$ OVA in sterile saline. In other experiments for intervention, $100 \mu \mathrm{g} / \mathrm{kg}$ of recombinant murine OX $40 \mathrm{~L}$ protein, $12 \mathrm{mg} / \mathrm{kg}$ of neutralizing anti-OX40L antibody or $5 \times 10^{6}$ isolated $\mathrm{OX} 40^{+} \mathrm{T}$ cells or PBS (control) were injected intravenously through the tail vein following anesthesia $(20,21)$.

Cytokine and protein measurements in bronchoalveolar lavage fluid $(B A L F)$. BALF was collected by flushing $1 \mathrm{ml}$ ice-cold PBS back and forth three times through a tracheal cannula followed by centrifugation at $2,000 \times \mathrm{g}$ at $4{ }^{\circ} \mathrm{C}$ for $10 \mathrm{~min}$, as previously described (22). Protein concentrations of IL-4, IL-6, IL-13, IL-17, TNF- $\alpha$ and IFN- $\gamma$ in the supernatant were measured using murine cytokine-specific ELISA kits (Invitrogen; Thermo Fisher Scientific, Inc.), according to the manufacturer's protocol. The concentration of IL-4, IL-6, IL-13, IL-17, TNF- $\alpha$ and IFN- $\gamma$ in the BALF were measured as markers of inflammatory reaction using a microplate reader at 450 nm (Thermo Fisher Scientific, Inc.; catalog no. 51119000).

Determination of eosinophils. Eosinophils were detected and counted as previously described (23). Briefly, BALF was performed by instilling $0.9 \% \mathrm{NaCl}$ containing $0.6 \mathrm{mmol} / \mathrm{l}$ EDTA in two separate $0.5 \mathrm{ml}$ aliquots. The fluid was recovered by gentle suction and placed on ice for immediate processing. An aliquot of $\sim 0.5 \mathrm{ml}$ BALF was processed immediately for eosinophil count. BALF cell suspensions were stained with 
PE-conjugated rat anti-mouse CCR 3 at $4^{\circ} \mathrm{C}$ for 30 min (1:500; R\&D Systems, Inc.; catalog no. FAB1551T-100UG), followed by staining with fluorescein isothiocyanate-conjugated anti-mouse CD16 (1:500; Antigenix America Inc., Huntington Station, NY, USA; catalog no. RM160323) for $30 \mathrm{~min}$ at $4^{\circ} \mathrm{C}$ in the dark. Samples stained with non-immunized rat IgG mAb (1:100; R\&D Systems, Inc.; catalog no. IC005P) for $30 \mathrm{~min}$ at $4^{\circ} \mathrm{C}$ were used as an isotype control. The percentage of eosinophils $\left(\mathrm{CCR} 3^{+} \mathrm{CD} 16^{-}\right)$was calculated as the number of eosinophils divided by the total number of cells in the BALF sample, as determined by flow cytometry and were analyzed with FlowJo software (version 7.6). All analyses were performed in a blinded fashion. The remainder of the lavage fluid was centrifuged at $1,000 \times \mathrm{g}$ for $10 \mathrm{~min}$ at $4^{\circ} \mathrm{C}$ and the supernatant was removed aseptically and stored in individual aliquots at $-80^{\circ} \mathrm{C}$.

Western blot analysis. Cell pellets $\left(1 \times 10^{7}\right)$ from fresh BALF collected from lung tissues was homogenized in $600 \mathrm{ml}$ radioimmunoprecipitation assay lysis buffer (Beyotime Institute of Biotechnology; catalog no. P0013B) in the presence of protease inhibitors for $30 \mathrm{~min}$ at $4^{\circ} \mathrm{C}$. Protein concentration was determined with the Bradford assay. Lysates were centrifuged at $9,000 \times \mathrm{g}$ for $15 \mathrm{~min}$ at $4^{\circ} \mathrm{C}$. Samples $(20 \mu \mathrm{g} /$ lane) were boiled for $5 \mathrm{~min}$ at $100^{\circ} \mathrm{C}$ and separated by $12 \%$ SDS-PAGE under denaturing conditions and electroblotted to a polyvinylidene difluoride membrane (Bio-Rad Laboratories, Inc., Hercules, CA). Membranes were blocked with PBS and 5\% non-fat dry milk for $12 \mathrm{~h}$ at $4^{\circ} \mathrm{C}$ and incubated with the following anti-

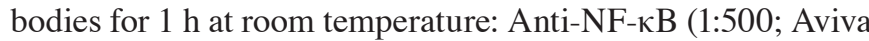
Systems Biology; catalog no. OAAI00072; p-Ser337) and anti-cleaved caspase 3 (1:500; Abbexa Ltd., Cambridge, UK; catalog no. abx015533). Immunoblot assays were then washed and incubated with a horseradish peroxidase-labeled secondary antibody (1:5,000 dilution; GE Healthcare Life Sciences, Shanghai, China; catalog nos. RPN4301 and RPN4201) for $1 \mathrm{~h}$ at room temperature. Protein bands were visualized using ECL Plus Enhanced Chemiluminescence Reagent (GE Healthcare Life Sciences), according to the manufacturer's protocol. Protein band intensity was determined relative to GAPDH using ImageJ software (version 2.1.4.7; National Institutes of Health, Bethesda, MD, USA).

Cell proliferation assay in vitro. The CCK- 8 assay was used to evaluate proliferation of isolated T cells. T cells were exposed to increasing concentrations of OX40L protein $(10,50,100$ or $200 \mathrm{ng} / \mathrm{ml}$ ) or $200 \mathrm{ng} / \mathrm{ml}$ of OX40L protein combined with $200 \mathrm{ng} / \mathrm{ml}$ of neutralizing anti-OX40L antibody. Briefly, T cells $\left(3 \times 10^{3}\right.$ cells/well) were seeded in each well of a 96 -well plate and stimulated with $0.10 \mathrm{mg} / \mathrm{ml}$ phytohemagglutinin (Thermo Fisher Scientific, Inc.; catalog no. 00-4977-93) for $24 \mathrm{~h}$. Subsequently, the cells were cultured in serum-free DMEM for $24 \mathrm{~h}$ starvation at $37^{\circ} \mathrm{C}$. Cells were treated with different concentrations of OX40L protein (10-200 ng/ml) or $200 \mathrm{ng} / \mathrm{ml}$ OX40L protein and $200 \mathrm{ng} / \mathrm{ml}$ neutralizing anti-OX40L antibody $(200 \mathrm{ng} / \mathrm{ml})$ for $24 \mathrm{~h}$ at $37^{\circ} \mathrm{C}$, and the proliferative activity was determined by $\mathrm{CCK}-8$ assay, according to the manufacturer's protocol. CCK-8 $(10 \mu \mathrm{l})$ was added to each well followed by incubation for an additional $2-4 \mathrm{~h}$ at $37^{\circ} \mathrm{C}$. When the media changed from red to yellow, the absorbance value

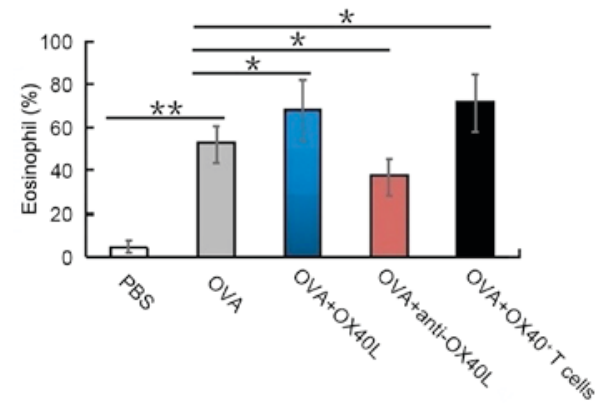

Figure 1.Effects of OX40/OX40L signaling on recruitment of allergen-induced BALF eosinophils in response to OVA treatment. The eosinophil count in the BALF of OVA-treated mice was significantly increased. Furthermore, the number of eosinophils in BALF significantly increased in OX40L protein- and $\mathrm{OX} 40^{+} \mathrm{T}$ cell-treated mice sensitized and challenged with OVA compared with OVA-treated mice. Data are presented as percent of total cells \pm SEM; $\mathrm{n}=6-8$ mice/group; ${ }^{*} \mathrm{P}<0.05,{ }^{* *} \mathrm{P}<0.01$. BALF, bronchoalveolar lavage fluid; OVA, ovalbumin; OX40L, OX40 ligand.

was detected at a wavelength of $450 \mathrm{~nm}$ using a microplate reader (Thermo Fisher Scientific, Inc.; catalog no. 51119000). The experiment was performed at least three times.

Flow cytometric analysis of cell apoptosis. Mononuclear $\mathrm{T}$ cells were isolated from BALF according to a previously described procedure with some modifications (24). Briefly, $\mathrm{T}$ cells $\left(1 \times 10^{5}\right.$ cells/test) were washed twice with PBS and centrifuged at $1,000 \mathrm{x} \mathrm{g}$ for $5 \mathrm{~min}$ at room temperature. Each pellet $\left(\sim 1 \times 10^{5}\right.$ cells) of the $\mathrm{T}$ cells was then re-suspended in $400 \mu \mathrm{l}$ PBS followed by incubation with $5 \mu \mathrm{l}$ Annexin V and $1 \mu \mathrm{l}$ propidium iodide (PI; $1 \mathrm{mg} / \mathrm{ml}$ ) for $15 \mathrm{~min}$ at room temperature. Cells were subsequently analyzed using a flow cytometer without washing the cells. Cells that were PI and Annexin V negative were considered healthy cells, PI negative and Annexin $\mathrm{V}$ positive were considered apoptotic and cells that were PI and Annexin V positive were considered necrotic.

Statistical analysis. Data are presented as the mean \pm standard error of the mean. Statistical analyses were performed using SPSS 18.0 software package (SPSS Inc., Chicago, IL, USA). Comparisons among multiple groups were performed using one-way analysis of variance followed by the Bonferroni post-hoc test if the data were normally distributed. $\mathrm{P}<0.05$ was considered to indicate a statistically significant difference.

\section{Results}

OX40/OX40L signaling effects on eosinophil recruitment in lungs following sensitization and challenge with OVA. The presence of eosinophils in the BALF and lungs is an important indicator of airway inflammation (25). OVA challenged mice had a significantly higher eosinophil count $(56 \pm 6.8 \%)$ compared with PBS-treated control mice $(4.4 \pm 3.6 \% ; \mathrm{P}<0.01)$; OX40L protein-treated mice and $\mathrm{OX}_{40}{ }^{+} \mathrm{T}$ cell-treated mice also had a high eosinophil count $(65 \pm 5.5$ and $67 \pm 7.2 \%$, respectively) in the BALF following sensitization and challenge with OVA (Fig. 1), compared with those treated with OVA alone. By contrast, eosinophils accounted for only $41 \pm 4.5 \%$ of all cells in the BALF of mice treated with neutralizing anti-OX40L 

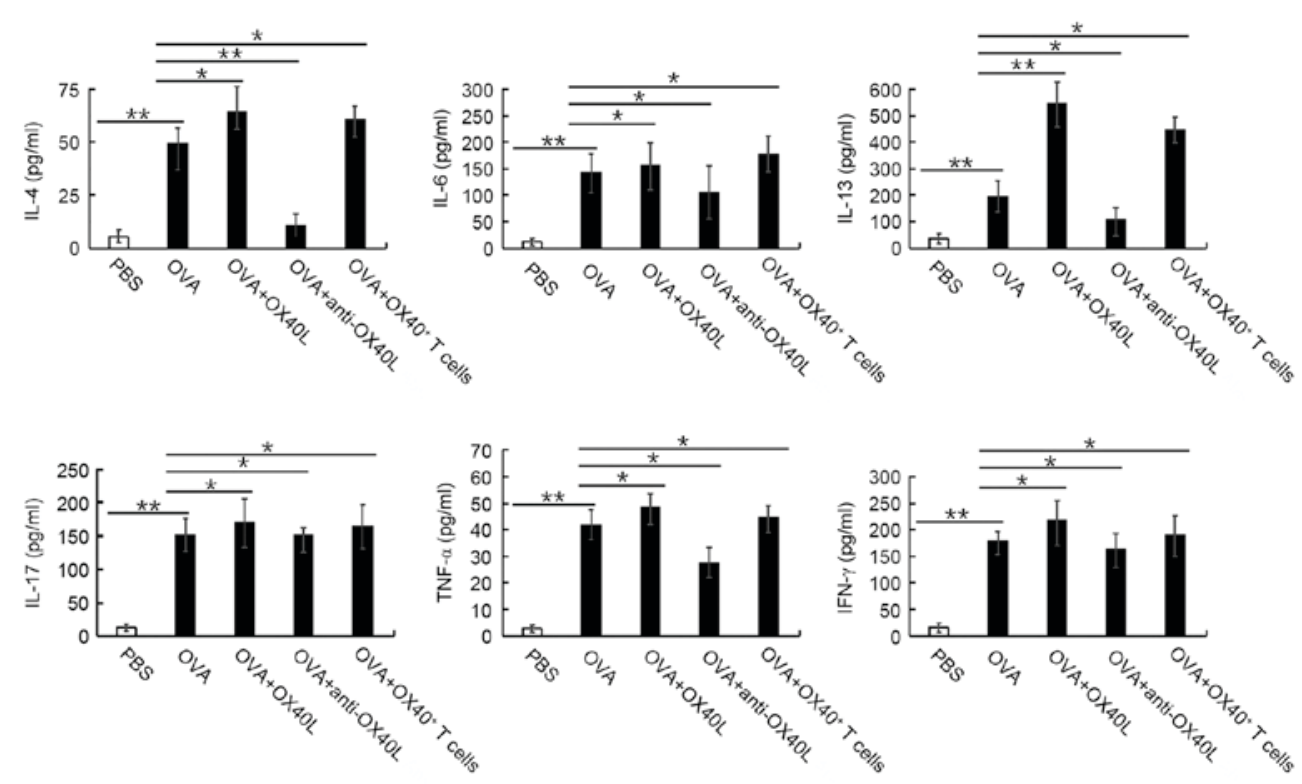

Figure 2. Effects of OX40/OX40L signaling on cytokine secretion in BALF in response to OVA treatment. Expression levels of the cytokines IL-4, IL-6, IL-13, IL-17, TNF- $\alpha$ and IFN- $\gamma$ were measured by ELISA in the BALF of PBS treated mice and in mice treated with OVA, OVA + OX40L protein, OVA + neutralizing anti-OX40L antibody, and OVA + OX40 ${ }^{+} \mathrm{T}$ cells. Data are shown as $\mathrm{pg} / \mathrm{ml} \pm \mathrm{SEM}, \mathrm{n}=6-8$ mice/group; ${ }^{*} \mathrm{P}<0.05,{ }^{* *} \mathrm{P}<0.01$. BALF, bronchoalveolar lavage fluid; IFN, interferon; IL, interleukin; OVA, ovalbumin; OX40L, OX40 ligand; TNF, tumor necrosis factor.

\section{A}

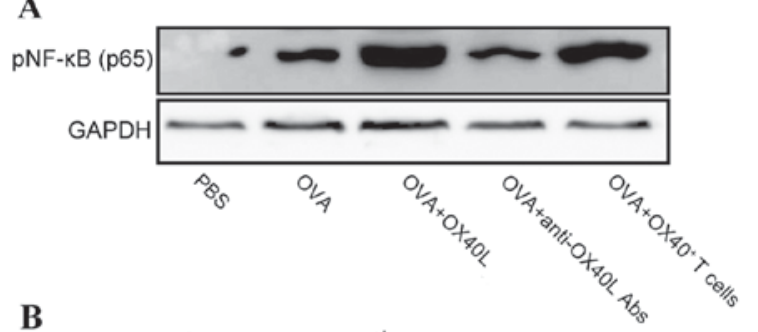

B

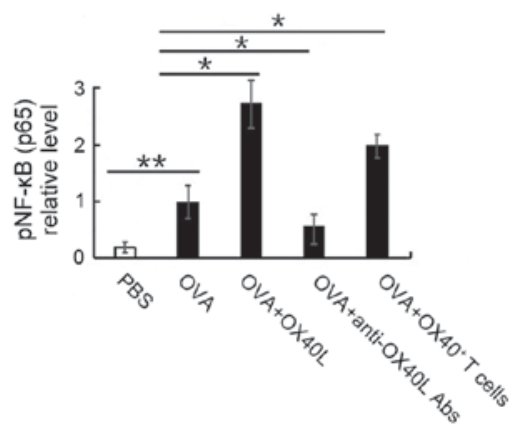

Figure 3. Effects of OX40/OX40L signaling effect on pNF-кB expression in BALF in response to OVA treatment. (A) Representative western blotting results from three independent experiments. (B) Ratios of pNF-kB to GAPDH protein bands of PBS treated mice and mice treated with OVA, OVA + OX40L protein, OVA + neutralizing anti-OX40L antibody, and $\mathrm{OVA}+\mathrm{OX} 40^{+} \mathrm{T}$ cells. All values represent mean $\pm \mathrm{SEM} ; \mathrm{n}=6-8$ mice/group; ${ }^{*} \mathrm{P}<0.05$. BALF, bronchoalveolar lavage fluid; NF, nuclear factor OVA, ovalbumin; OX40L, OX40 ligand.

antibody (Fig. 1). These results suggested that OX40/OX40L signaling may serve an important role in eosinophil recruitment into the lungs.

Effects of OX40/OX40L signaling on cytokine expression levels in vivo. Mice challenged with OVA exhibited a significant increase in IL-4, IL-6, IL-13, IL-17, TNF- $\alpha$ and
IFN- $\gamma$ expression levels in BALF, compared with the levels in untreated mice $(\mathrm{P}<0.05$; Fig. 2). In mice sensitized and challenged with OVA that were co-treated with neutralizing anti-mouse OX40L antibody, this increase in IL-4, IL-6, IL-13, IL-17, TNF- $\alpha$ and IFN- $\gamma$ cytokine levels was significantly suppressed $(\mathrm{P}<0.05$ or $\mathrm{P}<0.01$ vs. OVA; Fig. 2 ); whereas mice co-treated with $\mathrm{OX} 40 \mathrm{~L}$ protein or $\mathrm{OX} 40^{+} \mathrm{T}$ cells exhibited a significant increase in these cytokine levels in the BALF ( $\mathrm{P}<0.05$ or $\mathrm{P}<0.01$; Fig. 2), compared with the levels the OVA group. These results suggested that OX40/OX40L signaling may significantly increase the IL-4, IL-6, IL-13, IL-17, TNF- $\alpha$ and IFN- $\gamma$ cytokine levels in the BALF.

NF- $\kappa \mathrm{B}$ activation promotes inflammatory cell migration and proliferation, and mediates inflammatory factor secretion (26). To determine whether OX40/OX40L signaling is able to effect NF- $\mathrm{KB}$ activation, the expression of activated $\mathrm{NF}-\mathrm{\kappa B}$ was detected in inflammatory cells from the BALF. Activated NF- $\mathrm{KB}$ expression was significantly increased in the OVA-challenged group compared with the PBS group $(\mathrm{P}<0.01)$. Furthermore, $\mathrm{pNF}-\kappa \mathrm{B}$ expression was significantly increased in $\mathrm{OX} 40 \mathrm{~L}$ protein or $\mathrm{OX} 40^{+} \mathrm{T}$ cell-treated mice and significantly reduced in anti-OX40L antibody-treated mice compared with mice in the OVA group (Fig. 3). These results indicated that OX40/OX40L signaling may induce $\mathrm{NF}-\kappa \mathrm{B}$ activation and suggests that OX40/OX40L signaling had a pro-inflammatory effect by regulating the expression of IL-4, IL-6, IL-13, IL-17, TNF- $\alpha$ and IFN- $\gamma$ through NF-кB activation.

Effects of OX40/OX40L signaling on proliferation and polarization of $\mathrm{CD}^{+} \mathrm{T}$ cells in vitro. It has been previously reported that $\mathrm{OX} 40 \mathrm{~L}$ promoted the number of $\mathrm{OX} 40^{+} \mathrm{CD} 4 \mathrm{~T}$ cells in an asthma model (27), which indicated that OX40/OX40L signaling may serve an important role in the process of $\mathrm{CD}^{+} \mathrm{T}$ cell polarization, which may eventually affect the 
A
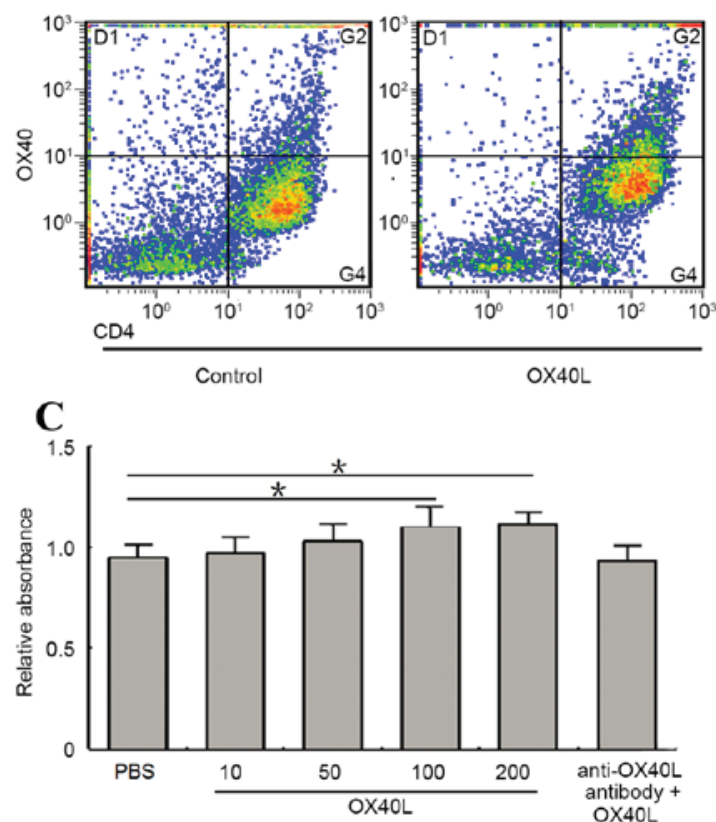

B
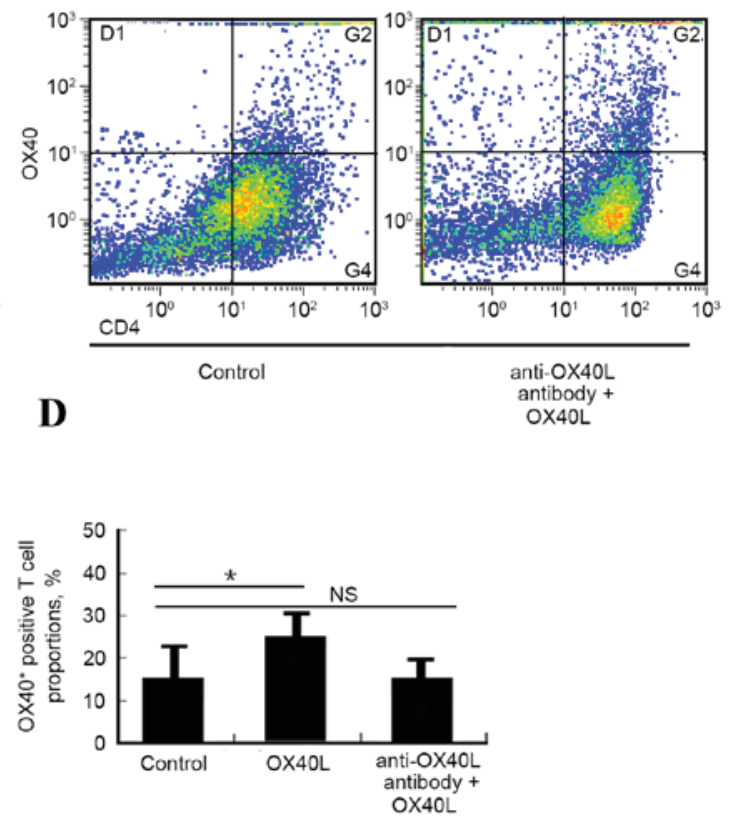

Figure 4. Effects of OX40/OX40L signaling on T cell proliferation and polarization. (A and B) Flow cytometric analysis of OX40+ $\mathrm{T}$ cell polarization in vitro. Representative results from 3-4 tests of $\mathrm{CD}^{+} / \mathrm{OX} 40^{+} \mathrm{T}$ cells from control PBS-treated, OX40L protein-treated or OX40L protein + neutralizing anti-OX40L antibody-treated groups. Absorbance was detected using a microplate reader at a wavelength of $450 \mathrm{~nm}$ in cells treated with (C) different concentrations of OX40L protein $(\mathrm{ng} / \mathrm{ml})$ or $200 \mathrm{ng} / \mathrm{ml}$ OX40L protein $+200 \mathrm{ng} / \mathrm{ml}$ neutralizing anti-OX40L antibody; All values represent mean \pm SEM; $n=3$; ${ }^{*} \mathrm{P}<0.05 \mathrm{vs.}$ PBS group. (D) Proportion of $\mathrm{OX} 40^{+} / \mathrm{OX} 40^{+} \mathrm{T}$ cells from (A and B), respectively. All values are presented as the mean $\pm \mathrm{SEM}$; $\mathrm{n}=5$; ${ }^{*} \mathrm{P}<0.05$. NS, not significant; OX40L, OX40 ligand.

A

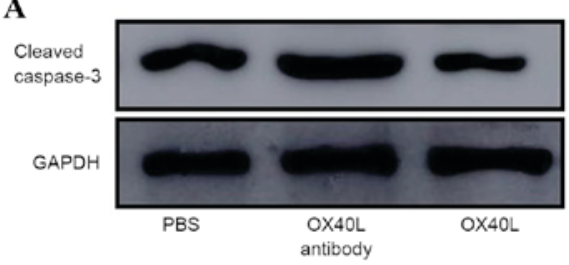

C

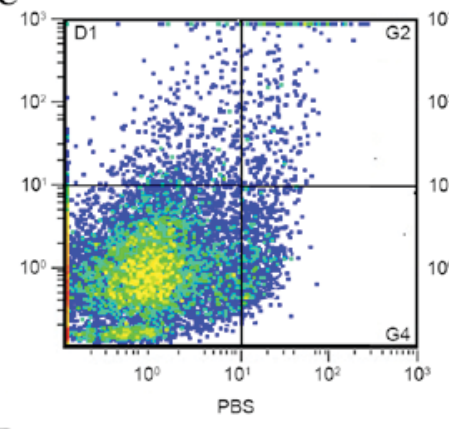

D

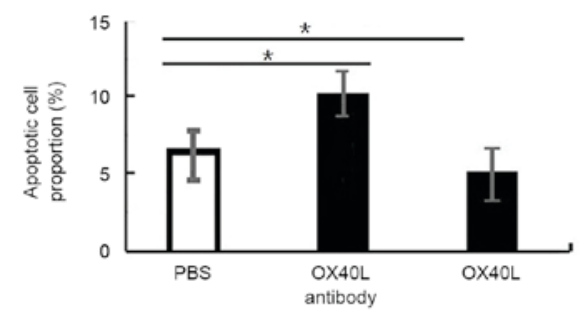

B
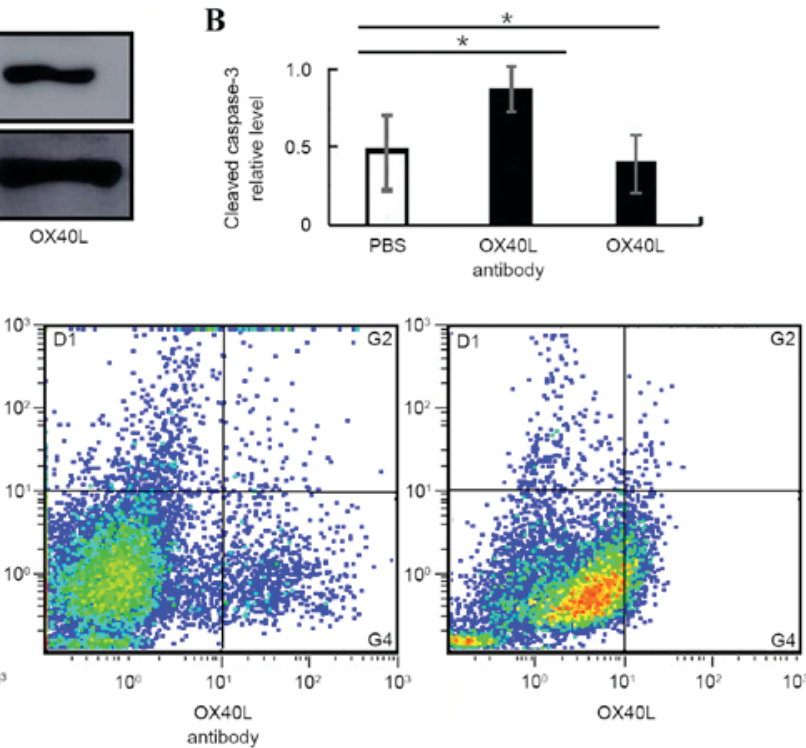

antibody

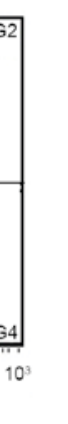


progression of asthma. The present study examined the effects of OX40/OX40L signaling on CD4 $\mathrm{T}$ cell proliferation and polarization in vitro. $\mathrm{CD} 4^{+} \mathrm{T}$ cells isolated from mouse spleen cultured with 100 or $200 \mathrm{ng} / \mathrm{ml}$ OX40L protein exhibited a significant increase in proliferation, whereas no change in proliferation was detected between the OX40L protein and neutralizing anti-OX40L antibody co-culture group and the PBS-treated control group (Fig. 4A). Furthermore, OX40L treatment significantly promoted the number of $\mathrm{OX} 40^{+} \mathrm{T}$ cells, whereas co-treatment with neutralizing anti-OX40L antibody suppresses $\mathrm{OX} 40^{+} \mathrm{T}$ cell number (Fig. 4B-D). These data indicated that OX40/OX40L signaling may be involved in $\mathrm{CD}^{+}$ $\mathrm{T}$ cell proliferation and polarization, and thus influences $\mathrm{T}$ cell bio-function in asthma pathology.

OX40/OX40L signaling effects on $T$ cell apoptosis in lungs following sensitization and challenge with OVA. To further explore the mechanism underlying OX40/OX40L signaling involved in asthma process, the expression levels of apoptosis-related protein cleaved caspase- 3 were examined in isolated T cells from PBS-treated, OX40L protein-treated or neutralizing anti-OX40L antibody-treated mice. Western blot analysis demonstrated that the relative protein expression level of cleaved-caspase- 3 was significantly increased in anti-OX40L antibody-treated mice $(0.87 \pm 0.11)$ and decreased in OX40L protein-treated mice $(0.36 \pm 0.18)$ compared with PBS-treated mice $(0.51 \pm 0.17 ; \mathrm{P}<0.05$ Fig. $5 \mathrm{~A}$ and $\mathrm{B})$. Similar results were obtained by flow cytometric analyses for apoptosis (Fig. 5C and D).

\section{Discussion}

OX40/OX40L signaling serves a key role in the development, differentiation and physiological functions of $\mathrm{T}$ cells and other immunological cells (28). The expression of OX40 is upregulated on activated T cells (29), whereas it is constitutively expressed on $\mathrm{T}$ regulatory cells $(30,31)$. This difference in expression is consistent with the previously hypothesized role of OX40/OX40L interactions in the propagation of the immune response and in initial $\mathrm{T}$ cell priming (32). OX40L is predominantly expressed in APCs, such as B cells, macrophages, microglia, dendritic cells and endothelial cells (33-39). Signaling through OX40/OX40L interactions during effector $\mathrm{T}$ cell responses has been previously reported to enhance $\mathrm{T}$ cell survival $(40,41)$, cytokine production (42) and increase the number of memory $\mathrm{CD}^{+} \mathrm{T}$ cells (43). Experimental models of autoimmunity and inflammation have indicated the potential role for OX40/OX40L, as inhibiting the interaction between OX40 and OX40L attenuates disease progression or severity $(44,45)$. Owing to this important role in the pathological process of numerous diseases, the present study examined the effects and the mechanisms of OX40/OX40L signaling in experimentally induced asthma.

A number of previous in vivo studies $(15,46-48)$ have demonstrated a pathogenic role for OX40/OX40L signaling in autoimmune diseases, and the disruption of this axis was reported to be beneficial for prevention and treatment (49). However, whether OX40/OX40L serves pathogenic roles in human asthma requires further exploration. Our previous study demonstrated that OX40L was overexpressed by myeloid APCs in peripheral blood and BALF in a mouse asthma model (27). Another previous study reported that the number of OX40L-expressing myeloid APCs was positively correlated with disease activity, as assessed by intrafluid expression of inflammatory factors (50). In the present study, the results indicated that OX40/OX40L signaling promoted $\mathrm{CD} 4^{+} \mathrm{T}$ cell proliferation and polarization into $\mathrm{CD} 4^{+} \mathrm{OX} 40^{+} \mathrm{T}$ cells, as evidenced by the significantly increased proportion of $\mathrm{CD} 4^{+} \mathrm{OX} 40^{+} \mathrm{T}$ cells present when $\mathrm{OX} 40 \mathrm{~L}$ was administered to isolated $\mathrm{T}$ cells from experimental mice in vitro. Conversely, $\mathrm{CD}^{+} \mathrm{T}$ cell proliferation was suppressed in cells co-treated with the neutralizing anti-mouse OX40L antibody. These observations suggest that OX40/OX40L interactions may have activated $\mathrm{CD} 4{ }^{+} \mathrm{OX} 40^{+} \mathrm{T}$ cells and this event may represent a crucial component for affecting the progression of experimental asthma (51).

Although OX40/OX40L signaling inhibition was demonstrated to reduce inflammation, as determined by its effect on IL-4, IL-6, IL-13, IL-17, TNF- $\alpha$ and IFN- $\gamma$ expression in peripheral blood and bronchoalveolar lavage fluid, there are still many signal transduction processes that may be involved in the pathogenesis of asthma progression, which makes these types of investigations very complex. Previous studies have focused on NF- $\mathrm{KB}$ signaling, which is necessary for the proliferation and migration of cells, the expression of multiple cytokines and the inflammatory response (52). The present study examined activated NF- $\mathrm{\kappa B}$ expression in asthma lung tissues by western blot analysis and demonstrated that activated NF- $\mathrm{KB}$ expression was elevated in OX40L protein- and $\mathrm{CD} 4{ }^{+} \mathrm{OX} 40^{+} \mathrm{T}$ cell-treated groups, and it was decreased in anti-OX40L antibody treated group, suggesting that OX40/OX40L interactions may affect asthma progression through the NF- $\mathrm{KB}$ pathway. Song et al (53) reported that the activation of NF- $\mathrm{KB} 1$ by OX40 contributes to antigen-driven T cell expansion and survival. Burrows et al (54) demonstrated that OX40 blockade inhibits house dust mite-driven allergic lung inflammation in mice and allergic responses in humans in vitro. The effects of OX40/OX40L on $\mathrm{T}$ cell function and the inflammatory response through the NF- $\kappa \mathrm{B}$ pathway demonstrated in these previous reports is consistent with the results of the present study.

Inflammatory responses are important factors for asthma-induced lung injury (55-57). During the acute pathological process, inflammatory cells (including neutrophils and macrophages) are recruited into lung lesions, where they are induced to secret pro-inflammatory cytokines to further accelerate inflammatory responses and promote asthma (58). Therefore, effective blocking or inhibiting of the inflammatory responses may be a fundamental treatment strategy for asthma. OX40/OX40 L interaction is a promoting factor in pathological processes of asthma (59). Consistently, OX40/OX40L interactions in the present study were also demonstrated to promote inflammatory cell infiltration and facilitated pro-inflammatory cytokine expression. A clear association has been demonstrated between an experimental model of asthma and the regulation of the inflammatory response by OX40/OX40L $(60,61)$.

In conclusion, although it requires further exploration, OX40/OX40L signaling may be a prospective intervention target for inhibiting $\mathrm{CD} 4^{+} \mathrm{OX} 40^{+} \mathrm{T}$ cell activation, inflammatory factor secretion and inflammatory cell infiltration into BALF 
in clinical settings of asthma therapy. Results from the present study revealed that the neutralizing anti-mouse OX40L antibody was an efficient inhibitor of $\mathrm{CD} 4{ }^{+} \mathrm{OX} 40^{+} \mathrm{T}$ cell production in OVA-induced asthma, and this inhibiting effect may further impact IL-4, IL-6, IL-13, IL-17, TNF- $\alpha$ and IFN- $\gamma$ expression, reduce inflammatory responses and thus alleviate asthma progression. Targeting of the OX40/OX40L axis may provide therapeutic effects in the treatment of asthma.

\section{Acknowledgements}

This study was supported by The National Natural Science Foundation of China (grant nos. 81300026 and 31600736), The Science and Education of Public Health Project for Young Medical Talents of Jiangsu Province (grant nos. QNRC2016747 and QNRC2016718), The Societal and Developmental Project of Suzhou (grant no. SS201630), The Suzhou Key Laboratory for Respiratory Medicine (grant no. SZS201617) and The Clinical Medical Center of Suzhou (grant no. Szzx201502).

\section{References}

1. Blume C and Davies DE: In vitro and ex vivo models of human asthma. Eur J Pharm Biopharm 84: 394-400, 2013.

2. Kumar RK and Foster PS: Modeling allergic asthma in mice: Pitfalls and opportunities. Am J Respir Cell Mol Biol 27: 267-272, 2002

3. Saw S, Kale SL and Arora N: Serine protease inhibitor attenuates ovalbumin induced inflammation in mouse model of allergic airway disease. PLoS One 7: e41107, 2012.

4. Hamid Q and Tulic M: Immunobiology of asthma. Annu Rev Physiol 71: 489-507, 2009.

5. Paul WE and Zhu J: How are $\mathrm{T}(\mathrm{H}) 2$-type immune responses initiated and amplified? Nat Rev Immunol 10: 225-235, 2010

6. Busse WW and Lemanske RF Jr: Asthma. N Engl J Med 344: 350-362, 2001.

7. Holgate ST: Pathogenesis of asthma. Clin Exp Allergy 38: 872-897, 2008

8. Medoff BD, Thomas SY and Luster AD: T cell trafficking in allergic asthma: The ins and outs. Annu Rev Immunol 26 205-232, 2008

9. Schuijs MJ, Willart MA, Hammad $\mathrm{H}$ and Lambrecht BN: Cytokine targets in airway inflammation. Curr Opin Pharmacol 13: 351-361, 2013.

10. Koshy S, Huq R, Tanner MR, Atik MA, Porter PC, Khan FS, Pennington MW, Hanania NA, Corry DB and Beeton C: Blocking KV1.3 channels inhibits Th2 lymphocyte function and treats a rat model of asthma. J Biol Chem 289: 12623-12632, 2014.

11. Webb GJ, Hirschfield GM and Lane PJ: OX40, OX40L and autoimmunity: A comprehensive review. Clin Rev Allergy Immunol 50: 312-332, 2016.

12. Wang YH and Liu YJ: Thymic stromal lymphopoietin, OX40-ligand, and interleukin-25 in allergic responses. Clin Exp Allergy 39: 798-806, 2009.

13. Liu YJ: Thymic stromal lymphopoietin and OX40 ligand pathway in the initiation of dendritic cell-mediated allergic inflammation. J Allergy Clin Immunol 120: 238-244, 2007.

14. Seshasayee D, Lee WP, Zhou M, Shu J, Suto E, Zhang J, Diehl L, Austin CD, Meng YG, Tan M, et al: In vivo blockade of OX40 ligand inhibits thymic stromal lymphopoietin driven atopic inflammation. J Clin Invest 117: 3868-3878, 2007.

15. Croft M, So T, Duan W and Soroosh P: The significance of OX40 and OX40L to T-cell biology and immune disease. Immunol Rev 229: 173-191, 2009.

16. National Research and Council (US): Committee for the update of the guide for the care and use of laboratory animals: Guide for the care and use of laboratory animals. 8th edition. Washington (DC): National Academies Press (US), 2011.

17. Wu Q, Tang Y, Hu X, Wang Q, Lei W, Zhou L and Huang J: Regulation of Th1/Th2 balance through OX40/OX40L signalling by glycyrrhizic acid in a murine model of asthma. Respirology 21 : $102-111,2016$
18. Salek-Ardakani S, Song J, Halteman BS, Jember AG, Akiba H, Yagita H and Croft M: OX40 (CD134) controls memory T helper 2 cells that drive lung inflammation. J Exp Med 198: 315-324, 2003.

19. Lee MY, Lee JA, Seo CS, Ha H, Lee NH and Shin HK: Protective effects of Mentha haplocalyx ethanol extract (MH) in a mouse model of allergic asthma. Phytother Res 25: 863-869, 2011.

20. Malmström V, Shipton D, Singh B, Al-Shamkhani A, Puklavec MJ, Barclay AN and Powrie F: CD134L expression on dendritic cells in the mesenteric lymph nodes drives colitis in $\mathrm{T}$ cell-restored SCID mice. J Immunol 166: 6972-6981, 2001.

21. Haley KJ, Ciota A, Contreras JP, Boothby MR, Perkins DL and Finn PW: Alterations in lung collectins in an adaptive allergic immune response. Am J Physiol Lung Cell Mol Physiol 282: L573-L584, 2002.

22. Zhang M, Fei X, Zhang GQ, Zhang PY, Li F, Bao WP, Zhang YY and Zhou X: Role of neutralizing anti-murine interleukin-17A monoclonal antibody on chronic ozone-induced airway inflammation in mice. Biomed Pharmacother 83: 247-256, 2016.

23. Arestides RS, He H, Westlake RM, Chen AI, Sharpe AH, Perkins DL and Finn PW: Costimulatory molecule OX40L is critical for both Th1 and Th2 responses in allergic inflammation. Eur J Immunol 32: 2874-2880, 2002.

24. Li YY, Chang JW, Chou WC, Liaw CC, Wang HM, Huang JS, Wang CH and Yeh KY: Zoledronic acid is unable to induce apoptosis, but slows tumor growth and prolongs survival for non-small-cell lung cancers. Lung Cancer 59: 180-191, 2008.

25. Lucas CD, Dorward DA, Sharma S, Rennie J, Felton JM, Alessandri AL, Duffin R, Schwarze J, Haslett C and Rossi AG: Wogonin induces eosinophil apoptosis and attenuates allergic airway inflammation. Am J Respir Crit Care Med 191: 626-636, 2015.

26. Carrero R, Cerrada I, Lledó E, Dopazo J, García-García F, Rubio MP, Trigueros C, Dorronsoro A, Ruiz-Sauri A, Montero JA and Sepúlveda P: IL1 $\beta$ induces mesenchymal stem cells migration and leucocyte chemotaxis through NF- $\kappa$ B. Stem Cell Rev 8: 905-916, 2012.

27. Lei W, Zeng DX, Zhu CH, Liu GQ, Zhang XQ, Wang CG, Wang Q and Huang JA: The upregulated expression of OX40/OX40L and their promotion of $\mathrm{T}$ cells proliferation in the murine model of asthma. J Thorac Dis 6: 979-987, 2014.

28. Kow NY and Mak A: Costimulatory pathways: Physiology and potential therapeutic manipulation in systemic lupus erythematosus. Clin Dev Immunol 2013: 245928, 2013.

29. Gramaglia I, Weinberg AD, Lemon M and Croft M: OX40 ligand: A potent costimulatory molecule for sustaining primary CD4 T cell responses. J Immunol 161: 6510-6517, 1998.

30. Takeda I, Ine S, Killeen N, Ndhlovu LC, Murata K, Satomi S Sugamura K and Ishii N: Distinct roles for the OX40-OX40 ligand interaction in regulatory and nonregulatory $\mathrm{T}$ cells. J Immunol 172: 3580-3589, 2004.

31. Valzasina B, Guiducci C, Dislich H, Killeen N, Weinberg AD and Colombo MP: Triggering of OX40 (CD134) on CD4(+) $\mathrm{CD} 25+\mathrm{T}$ cells blocks their inhibitory activity: A novel regulatory role for OX40 and its comparison with GITR. Blood 105: 2845-2851, 2005.

32. Ekkens MJ, Liu Z, Liu Q, Whitmire J, Xiao S, Foster A, Pesce J, VanNoy J, Sharpe AH, Urban JF and Gause WC: The role of OX40 ligand interactions in the development of the Th2 response to the gastrointestinal nematode parasite Heligmosomoides polygyrus. J Immunol 170: 384-393, 2003.

33. Miura S, Ohtani K, Numata N, Niki M, Ohbo K, Ina Y, Gojobori T, Tanaka Y, Tozawa H, Nakamura M, et al: Molecular cloning and characterization of a novel glycoprotein, gp34, that is specifically induced by the human T-cell leukemia virus type I transactivator p40tax. Mol Cell Biol 11: 1313-1325, 1991.

34. Baum PR, Gayle RB III, Ramsdell F, Srinivasan S, Sorensen RA, Watson ML, Seldin MF, Baker E, Sutherland GR, Clifford KN, et al: Molecular characterization of murine and human OX40/OX40 ligand systems: Identification of a human OX40 ligand as the HTLV-1-regulated protein gp34. EMBO J 13: 3992-4001, 1994.

35. Stüber E, Neurath M, Calderhead D, Fell HP and Strober W: Cross-linking of OX40 ligand, a member of the TNF/NGF cytokine family, induces proliferation and differentiation in murine splenic B cells. Immunity 2: 507-521, 1995.

36. Stüber $\mathrm{E}$ and Strober W: The T cell-B cell interaction via OX40-OX40L is necessary for the T cell-dependent humoral immune response. J Exp Med 183: 979-989, 1996. 
37. Ohshima Y, Tanaka Y, Tozawa H, Takahashi Y, Maliszewski C and Delespesse G: Expression and function of OX40 ligand on human dendritic cells. J Immunol 159: 3838-3848, 1997.

38. Brocker T, Gulbranson-Judge A, Flynn S, Riedinger M, Raykundalia $\mathrm{C}$ and Lane P: CD4 T cell traffic control: In vivo evidence that ligation of OX40 on CD4 T cells by OX40-ligand expressed on dendritic cells leads to the accumulation of CD4 T cells in B follicles. Eur J Immunol 29: 1610-1616, 1999.

39. Imura A, Hori T, Imada K, Ishikawa T, Tanaka Y, Maeda M, Imamura S and Uchiyama T: The human OX40/gp34 system directly mediates adhesion of activated $\mathrm{T}$ cells to vascular endothelial cells. J Exp Med 183: 2185-2195, 1996.

40. Rogers PR, Song J, Gramaglia I, Killeen N and Croft M: OX40 promotes $\mathrm{Bcl}-\mathrm{xL}$ and $\mathrm{Bcl}-2$ expression and is essential for long-term survival of CD4 T cells. Immunity 15: 445-455, 2001

41. Kinnear G, Wood KJ, Marshall D and Jones ND: Anti-OX40 prevents effector T-cell accumulation and CD8+ T-cell mediated skin allograft rejection. Transplantation 90: 1265-1271,2010.

42. Flynn S, Toellner KM, Raykundalia C, Goodall M and Lane P CD4 T cell cytokine differentiation: The $\mathrm{B}$ cell activation molecule, OX40 ligand, instructs CD4 T cells to express interleukin 4 and upregulates expression of the chemokine receptor, Blr-1. J Exp Med 188: 297-304, 1998.

43. Vu MD, Clarkson MR, Yagita H, Turka LA, Sayegh MH and Li XC: Critical, but conditional, role of OX40 in memory $\mathrm{T}$ cell-mediated rejection. J Immunol 176: 1394-1401, 2006.

44. Murata K, Nose M, Ndhlovu LC, Sato T, Sugamura K and Ishii N: Constitutive OX40/OX40 ligand interaction induces autoimmune-like diseases. J Immunol 169: 4628-4236, 2002.

45. Ueno $\mathrm{H}$ and Blanco P: OX40/OX40L axis: Not a friend in autoimmunity. Oncotarget 6: 21779-21780, 2015.

46. Gough MJ and Weinberg AD: OX40 (CD134) and OX40L. Adv Exp Med Biol 647: 94-107, 2009.

47. Hori T: Roles of OX40 in the pathogenesis and the control of diseases. Int J Hematol 83: 17-22, 2006.

48. Redmond WL and Weinberg AD: Targeting OX40 and OX40L for the treatment of autoimmunity and cancer. Crit Rev Immunol 27: 415-436, 2007

49. Park BS, Hong GU and Ro JY: Foxp3(+)-Treg cells enhanced by repeated low-dose gamma-irradiation attenuate ovalbumin-induced allergic asthma in mice. Radiat Res 179: 570-583, 2013.

50. Obermeier F, Schwarz H, Dunger N, Strauch UG, Grunwald N, Schölmerich J and Falk W: OX40/OX40L interaction induces the expression of CXCR5 and contributes to chronic colitis induced by dextran sulfate sodium in mice. Eur J Immunol 33: 3265-3274, 2003.
51. Kay AB: The role of T lymphocytes in asthma. Chem Immunol Allergy 91: 59-75, 2006.

52. Yang T, Zhang X, Wang M, Zhang J, Huang F, Cai J, Zhang Q, Mao F, Zhu W, Qian $\mathrm{H}$ and Xu W: Activation of mesenchymal stem cells by macrophages prompts human gastric cancer growth through NF-кB pathway. PLoS One 9: e97569, 2014.

53. Song J, So T and Croft M: Activation of NF-kappaB1 by OX40 contributes to antigen-driven $\mathrm{T}$ cell expansion and survival. J Immunol 180: 7240-7248, 2008.

54. Burrows KE, Dumont C, Thompson CL, Catley MC, Dixon KL and Marshall D: OX40 blockade inhibits house dust mite driven allergic lung inflammation in mice and in vitro allergic responses in humans. Eur J Immunol 45: 1116-1128, 2015.

55. Robinson DP, Hall OJ, Nilles TL, Bream JH and Klein SL: $17 \beta$-estradiol protects females against influenza by recruiting neutrophils and increasing virus-specific CD8 T cell responses in the lungs. J Virol 88: 4711-4720, 2014.

56. Jandl K, Stacher E, Bálint Z, Sturm EM, Maric J, Peinhaupt M, Luschnig P, Aringer I, Fauland A, Konya V, et al: Activated prostaglandin D2 receptors on macrophages enhance neutrophil recruitment into the lung. J Allergy Clin Immunol 137: 833-843, 2016.

57. Jeon J, Kim Y, Kim H, Kang JS and Lee WJ: Anti-inflammatory effect of alloferon on ovalbumin-induced asthma. Immune Netw 15: 304-312, 2015.

58. Bouchard JC, Beal DR, Kim J, Vaickus LJ and Remick DG: Chemokines mediate ethanol-induced exacerbations of murine cockroach allergen asthma. Clin Exp Immunol 172: 203-216, 2013.

59. Farres MN, Sabry MK, Ahmed EE, Elkady HM and Mohamed NA: OX40 ligand: A potential costimulatory molecule in atopic asthma. J Asthma 51: 573-577, 2014.

60. Kaur D and Brightling C: OX40/OX40 ligand interactions in T-cell regulation and asthma. Chest 141: 494-499, 2012.

61. Lei W, Zhu CH, Zeng da X, Wang Q, Zhang XQ, Chen YB, Mu CY and Huang JA: SOX40L: An important inflammatory mediator in adult bronchial asthma. Ann Acad Med Singapore 41: 200-204, 2012

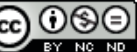

This work is licensed under a Creative Commons Attribution-NonCommercial-NoDerivatives 4.0 International (CC BY-NC-ND 4.0) License. 